\title{
RENDGENSKA DIFRAKTOMETRIJA PRAHA - XRPD
}

\author{
Vladimir D. Pavkov", *, \\ Gordana M. Bakić2 \\ Vesna Maksimović ${ }^{1}$ \\ Branko Matović, \\ Miloš Đukić ${ }^{2}$
}

${ }^{1}$ Institut za nuklearne nauke "Vinča", Univerzitet u Beogradu,

Beograd, Srbija.

2Univerzitet u Beogradu,

Mašinski fakultet,

Beograd, Srbija
Odgovorno lice:

Vladimir D. Pavkov

e-pošta:

pavkow@vin.bg.ac.rs

\section{Rezime:}

Nauka o materijalima danas predstavlja multidisciplinarnu oblast, gde na osnovu fizičke i hemijske karakterizacije materijala mogu da se definišu njihova svojstva kao i potencijalna primena. U cilju dobijanja finalnog proizvoda zahtevanih karakteristika, neophodno je primeniti savremene eksperimentalne metode za ispitivanje materijala, među kojima značajno mesto zauzima metoda rendgenske difrakcije. Metoda rendgenske difraktometrije praha XRPD predstavlja najjednostavniju, najtačniju, najbržu pa ujedno i najefikasniju metodu za identifikaciju materijala. Ova metoda je nedestruktivna, pa uzorak nakon ispitivanja ostaje sačuvan za dalju analizu. XRPD metodom se mogu lako razlikovati kristalne faze čak i kada imaju isti hemijski sastav. Iako mnoga jedinjenja mogu da imaju istu strukturu, tj. da im dijagram praha bude isti, rendgenska difrakcija sa velikom pouzdanošću indirektno pruža uvid u hemijsku analizu datog jedinjenja. U ovom radu predstavljeni su osnovni pojmovi metode rendgenske difraktometrije praha, njena primena i značaj u ispitivanju različitih materijala kao i identifikacija strukture bazalta pre i nakon termičkog tretmana.

Ključne reči:

Rendgenski zraci, difraktometar praha, Bragov zakon, difraktogram praha, bazalt.

\section{UVOD}

Ni jedno fizičko svojstvo materijala se ne može objasniti, a da se pri tome ne zna kakva je struktura tog materijala, odnosno kako se struktura menja pod različitim uslovima. Danas se praktično ne može zamisliti ispitivanje materijala bez rendgenske difrakcije. Rendgenska difrakcija (eng. X-Ray Diffraction, XRD) se može definisati kao nedestruktivna eksperimentalna metoda, koja se zasniva na korišćenju X-zraka i njegovoj difrakciji. Ova metoda se koristi za identifikaciju minerala kao i minerološkog sastava materijala, jer vrsta minerala određuje svojstva finalnog proizvoda kao i njegovu potencijalnu primenu.

Tokom proučavanja katodnih zraka 1895. godine, Vilhelm Konrad Rendgen je otkrio rendgenske zrake (Röntgenstrahlen) i kako nije poznavao njihovo poreklo nazvao ih je X-zraci. Rendgenski zraci su elektromagnetni talasi, što znači da su nosioci promenljivog elektromagnetnog polja. 
Čvrsto telo u kojem su atomi, joni ili molekuli, koji ga čine, rapoređeni pravilno po određenim zakonitostima i ponavljaju se u sve tri dimenzije naziva se kristal. Osnovna ponavljajuća jedinica koja definiše kristal naziva se jedinična ćelija.

Čvrste supstance se mogu pojaviti u sledećim oblicima:

- kao čisti monokristali ili monokristali koji sadrže nečistoće,

- kao polikristalni materijal koji je sačinjen od velikog broja različito orijentisanih kristalita jedne ili više kristalnih faza,

- kao tanki filmovi jedne faze nataložene na drugoj fazi i

- kao amorfne supstance i staklo.

Nijedna pojedinačna eksperimentalna metoda ne daje sveoubuhvatni odgovor na svojstva materijala, međutim činjenica je da je osnovna metoda za karakterizaciju kao i analizu polikristalnih materijala rendgenska difrakcija.

\section{RENDGENSKA DIFRAKTOMETRIJA PRAHA}

Materijal u sprašenom obliku koji se sastoji od više istovrsnih ili raznovrsnih sitnih kristala naziva se polikristalni materijal [1]. Rendgenska difraktometrija praha (eng. X-Ray Powder Diffraction, XRPD) se može definisati kao metoda za analizu i karakterizaciju polikristalnih materijala. Na osnovu ove metode mogu se dobiti podaci o materijalu koji se odnose na: fazni sastav, zastupljenost prisutnih faza, strukturu kao i mikronaprezanja [2].

Metodom rendgenske difraktomerije praha mogu se analizirati kako uzorci u obliku praha tako i masivni uzorci i tanki filmovi od nanometarskih do mikrometarskih veličina zrna, što daje ovoj metodi široku primenu u analizi različitih materijala (minerali, stene, metali, legure, keramički materijali, polimeri, karbonski materijali, kompoziti itd.). Veoma je važno istaći da je ova metoda izuzetno precizna i nedestruktivna odnosno uzorak se nakon ispitivanja može sačuvati i koristiti za dalju analizu. Dovoljna je jako mala količina materijala od 2 do 20 $\mathrm{mg}$ da bi se izvšila analiza ovom metodom [2].

Ispitivanje polikristalnog uzorka metodom difrakcije $\mathrm{u}$ cilju identifikacije prisutnih kristalnih faza naziva se kvalitativna rendgenska analiza. Ukoliko se vrši određivanje masenih udela pojedinih kristalnih faza u uzorku tada je reč o kvantitativnoj rendenskoj analizi [1].

\section{Rendgensko zračenje}

Da bi se dobili podaci o kristalnoj strukturi nekog materijala koristi se zračenje čija talasna dužina odgovara mađuatomskom rastojanju u kristalima, pri čumu takav uslov ispunjavaju rendgenski, odnosno X-zraci, koji se nalaze između ultraljubičastog i $\gamma$ - zračenja. Rendgenski zraci su elektromagnetni talasi koji se odlikuju: visokom frekvencijom, malom talasnom dužinom i visokom energijom. Opšte je poznato da rendgenski zraci imaju frekvenciju od $3 \cdot 10^{16}$ do $3 \cdot 10^{19} \mathrm{~Hz}$, talasnu dužinu između 0,01 i $10 \mathrm{~nm}$ i energiju od $120 \mathrm{eV}$ do $120 \mathrm{keV}$.

Mogu se razlikovati "meki” i "tvrdi” X-zraci u zavisnosti od vrednosti napona, odnosno pri nižim vrednostima napona dobijaju se "meki” X-zraci [3]. Dobro je poznato da "meki" rendgenski zraci (soft X-rays) imaju talasnu dužinu od 0,1 do $10 \mathrm{~nm}(0,12$ do $12 \mathrm{keV})$, dok "tvrdi" rendgenski zraci (hard X-rays) imaju talasnu dužinu od 0,01 do $0,1 \mathrm{~nm}(12$ do $120 \mathrm{keV})$.

$\mathrm{U}$ difrakcionoj analizi koristi se rendgensko zračenje malih talasnih dužina, što odgovara energijama fotona od $1 \mathrm{keV}$ do $120 \mathrm{keV}$. Kako je talasna dužina rendgenskog zračenja približna veličini atoma, primena ovog zračenja je pogodna za određivanje strukturnog uređenja atoma i molekula u različitim materijalima $[4,5]$. Zraci sa manjom talasnom dužinom imaju veću prodornost, pa tako prilikom korišćenja rendgenskog zračenja potrebno je pridržavati se propisanih zaštitnih mera na radu, s obzirom da X-zraci mogu biti izuzetno štetni po ljudsko zdravlje.

\section{Nastanak rendgenskog zračenja}

$\mathrm{U}$ atomu, elektroni su raspoređeni $\mathrm{u}$ orbitalama, odnosno ljuskama (K, L, M, N ...). Elektroni su u ljuskama vezani energijama koje su karakteristične za svaki element. Energija zavisi od privlačne sile jezgra koja zavisi od broja protona u njemu. Energija vezivanja elektrona u unutrašnjim ljuskama je veća od energije vezivanja elektrona u spoljašnjim ljuskama, pa se elektroni u unutrašnjim ljuskama nalaze u povoljnijem energetskom položaju. U susednim unutrašnjim ljuskama razlika u energijama vezivanja elektrona je veća nego između elektrona u spoljašnjim ljuskama.

Ukoliko se atomu, nekim procesom, ukloni elektron iz unutrašnje ljuske, na njegovom mestu će nastati vakancija (upražnjenost, nepopunjenost ili prazno mesto), slika 1. 


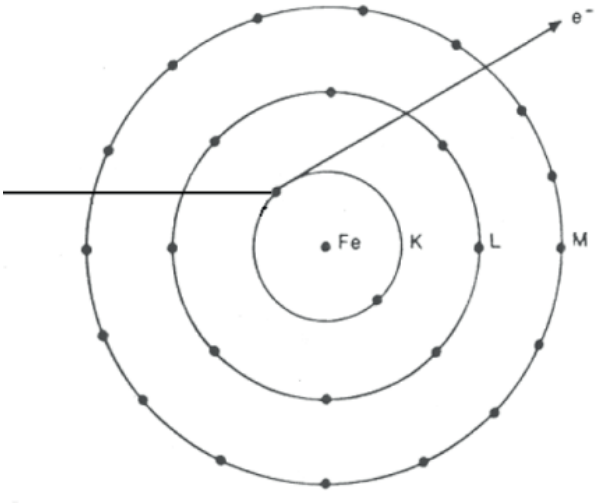

Slika 1. Uklanjanje elektrona iz atomske ljuske [6]

S obzirom da su atomi sa vakancijom u unutrašnjoj ljusci nestabilni, u jako kratkom vremenu će elektron iz neke od spoljašnjih ljuski preći na upražnjeno mesto. Kako elektroni iz spoljašnjih ljuski poseduju višu energiju, prilikom njihovog prelaza na upražnjeno mesto oslobodiće se energija u vidu karakterističnog rendgenskog zračenja, slika 2.

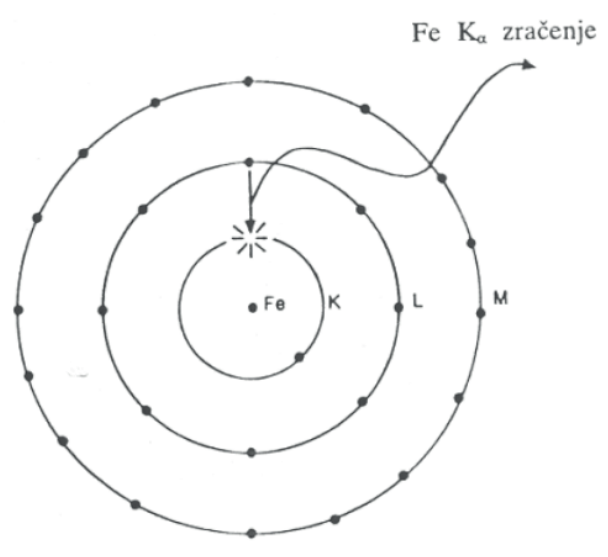

Slika 2. Nastanak rendgenskog zračenja [6]

U različitim unutrašnjim ljuskama mogu nastati vakancije pa tako elektroni mogu prelaziti sa različitih viših energetskih nivoa. Dakle, kod svakog elementa može nastati zračenje različitih energija, tj. talasnih dužina, odnosno mogu nastati različite linije karakterističnog zračenja.

U oblasti kristalografije, za dobijanje rendgenskih zraka koristi se rendgenska cev prikazana na slici 3 . Rendgenska cev predstavlja staklenu cev sa berilijumskim prozorima kroz koje izlazi rendgensko zračenje, a pritom je u potpunosti pod vakuumom. Rendgenski, odnosno X-zraci se stvaraju u vakuum cevi sa naponom od 30 do $150 \mathrm{kV}[1,2]$.

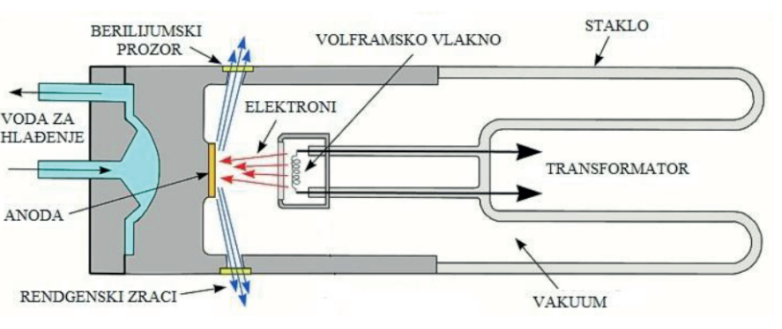

Slika 3. Šematski prikaz rendgenske cevi [7]

Katoda je zatopljena na jednoj strani rendgenske cevi, dok se anoda nalazi naspram nje. Namotano volframsko vlakno, koje predstavlja katodu, zagreva se do usijanja, a kao posledica toga dolazi do emitovanja termalnih elektrona. Termalni elektroni imaju usmereno kretanje sa katode na anodu, gde usled napona, od nekoliko desetina kilovolti, između ove dve elektrode dolazi do ubrzanja elektrona. Tokom udara elektrona $\mathrm{u}$ anodu dolazi do oslobađanja energije koja se potom pretvara u kontinualno odnosno "belo" zračenje i prolazi kroz berilijumske prozore na rendgenskoj cevi. Anoda je konstruisana tako da ima sistem hlađenja kroz koji struji voda u cilju sprečavanja njenog oštećenja usled pregrevanja.

Procesom galvanizacije može se naneti sloj metala na anodu, kao što su Fe, Cr ili Mo, u cilju dobijanja zračenja određene talasne dužine, odnosno karakterističnog zračenja. Snop elektrona poseduje dovoljnu energiju da izbije elektrone iz unutrašnjih ljuski nekog metala od kojeg je izrađena anoda, usled čega dolazi do oslobađanja energije određene talasne dužine. Dve najvažnije linije koje nastaju su: Ka linija (usled izbijanja elektrona sa K ljuske pri čemu je popunjava L ljuska) i K $\beta$ linija (usled prelaza elektrona sa M ljuske popunjavajući K ljusku) [2].

Važno je istaći da karakteristično rendgensko zračenje manje talasne dužine emituju elementi koji poseduju veći atomski broj $Z$. Najčešće se koriste rendgenske cevi sa bakarnom anodom talasne dužine 1,5443 Å ili molibdenskom anodom talasne dužine 0,7107 $\AA$ (Angstrem ( $\AA), 1 \AA=0,1 \mathrm{~nm}=10^{-10} \mathrm{~m}$ ).

$\mathrm{U}$ metodi rendgenske difrakcije praha koristi se rendgensko zračenje koje je monohoromatsko i koje se dobija uz pomoć kristala - monohromatora ili filtera. Monohromator ili filter je postavljen na put rendgenskim zracima ispred ili iza sprašenog uzorka u zavisnosti 
od opremljenosti difraktometra za prah. Kristal monohromatora može se napraviti od grafita, nikla, kvarca ili nekog drugog materijala.

\section{Princip rada difraktometra za prah}

Uređaj uz pomoć kojeg se može dobiti difraktogram praha polikristalnog materijala naziva se difraktometar za prah. Jednu od najvažnijih komponenti difraktometra za prah, predstavlja rendgenska cev uz pomoć koje se generiše rendgensko zračenje. Pored napomenute rendgenske cevi, difraktometar za praha se sastoji od sledećih elemenata: generator (izvor visokog napona), goniometar, detektor, sistem za hlađenje i računar.

Princip rada difraktometra za prah prikazan je na slici 4. Iz izvora rendgenskog zračenja, u ovom slučaju rendgenske cevi, rendgenski zraci prolaze kroz divergentni prorez. Sužen rendgenski zrak pada na pripremljeni, odnosno sprašeni uzorak koji je postavljen na nosač i nalazi se u osi goniometra. Difraktovani zraci sa površine uzorka prolaze kroz prijemne proreze, a potom ulaze u detektor koji se kreće konstantno po difraktometarskom krugu oko ose goniometra.

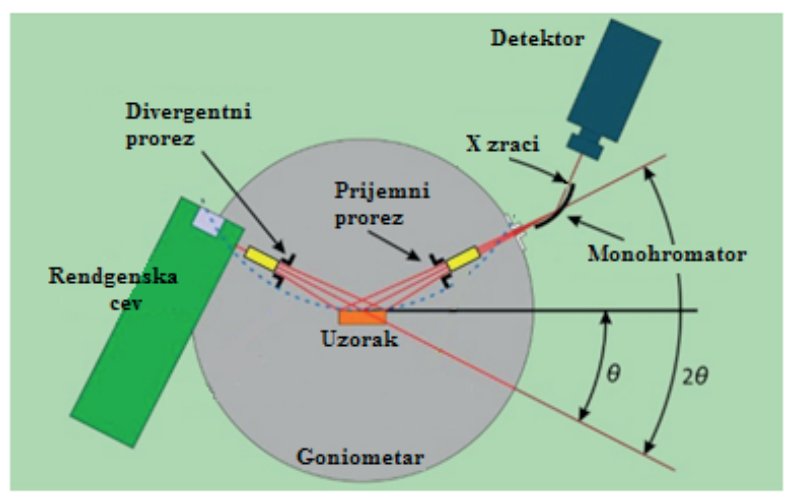

Slika 4. Princip rada difraktometra za prah ( $\theta-\theta$ geometrija) [8]

Kod $\theta$ - $\theta$ geometrije, kao što je prikazano na slici 4 , uzorak miruje $\mathrm{u}$ horizontalnom položaju, a istim brzinama zakreću se rendgenska cev i detektor. Ugao pod kojim rendgenski zraci padaju na sprašeni uzorak se menja tokom eksperimenta, a pri tome detektor registruje promene intenziteta difraktovanog zračenja. Zabeleženi impulsi u detektoru prenose se na brojački lanac, a potom se softverski obrađuju i dobija se difraktogram praha kao rezultat.
Dva kruga su karakteristična za parafokusnu geometriju, a to su fokusni i goniometarski krug. Na fokusnom krugu koji ima promenljiv radijus, prikazan je isprekidanom linijom na slici 5, nalaze se: izvor zračenja (I), uzorak (U) i detektor (D). Uzorak se istovremeno nalazi u centru goniometarskog kruga, prikazan punom linijom na slici 5, koji ima konstantan radijus (R) [9]. Pravilno postavljen uzorak za ispitivanje se nalazi u centru goniometarskog kruga dok istovremeno tangira fokusni krug.

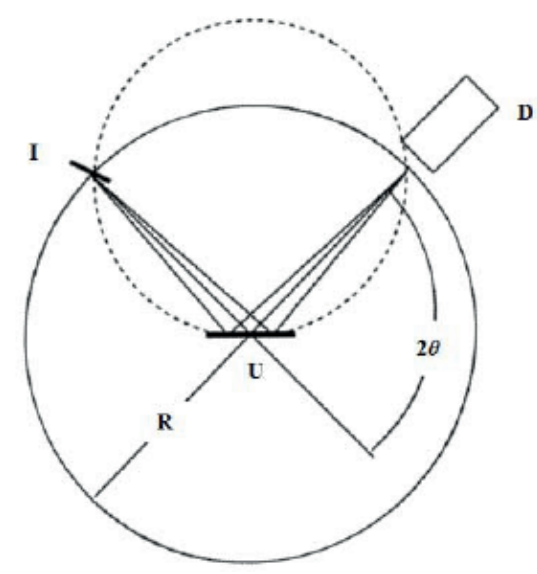

Slika 5. Izgled geometrije goniometra sa karakterističnim krugovima (fokusni i goniometarski krug) [9]

\section{Bragov zakon}

Rasipanje rendgenskih zraka je pojava do koje dolazi kada rendgenski zraci dođu u kontakt sa povšinom uzorka, odnosno polikristalim materijalom i tada atomi počinju da deluju kao sekundarni izvori zračenja. Do interakcije između rasutih rendgenskih zraka dolazi kada se deo talasa pojača, deo oslabi ili se u potpunosti međusobno poništi, pri čemu se ova pojava naziva difrakcija i u nastavku rada biće objašnjena Bragovim zakonom.

Niz ekvidistantnih ravni moguće je postaviti kroz kristalnu rešetku, pri čemu ove ravni predstavljaju zamišljene ravni koje se međusobno nalaze na istom ekvidistantnom rastojanju $d$. Ravni kristalne rešetke obeležavaju se Milerovim indeksima i predstavljaju cele brojeve. Milerovi indeksi predstavljaju recipročne vrednosti odsečaka koje data ravan pravi na kristalografskim osama. S obzirom da napomenute ravni deluju kao poluprovidna ogledala, pa se sa njih jedan deo zraka reflektuje sa gornje ravni, deo zraka može proći kroz nju i tako reflektovati sa sledeće ravni ili u potpunosti proći kroz ceo kristal $[1,10]$. 
Bragov zakon odnosno difrakcija rendgenskih zraka na ekvidistantnim ravnima u kristalu prikazana je na slici 6. Tri ravni $\mathrm{M}, \mathrm{N}$ i O se nalaze na istom ekvidistantnom rastojanju $d$. Na susedne ravni $\mathrm{M}$ i $\mathrm{N}$ padaju snopovi rendgenskih zraka A i B, talasne dužine $\lambda$. Sa slike 6 se jasno uočava da snop zraka BB' treba da pređe duži put od snopa AA' za deo CDE. Da bi se ostvarila konstruktivna interferencija, odnosno da bi zraci A' i B' bili u fazi, potrebno je da razlika puteva bude jednaka celom broju talasnih dužina, tj. $\mathrm{CDE}=n \lambda$. Ukoliko je $\mathrm{CD}=\mathrm{DE}$ $=d \sin \theta$, onda je $\mathrm{CDE}=2 d \sin \theta[1]$, pa sledi jednačina:

$n \lambda=2 d \sin \theta$.

Jednačina (1) predstavlja Bragovu jednačinu, odnosno Bragov zakon [11, 12, 13, 14], gde je:

$d$ - ekvidistantno rastojanje nekog niza kristalografskih ravni,

$\theta$ - upadni ugao zraka u odnosu na te ravni,

$n$ - ceo broj i ujedno označava red refleksije - spektra,

$\lambda$ - talasna dužina rendgenskih zraka.
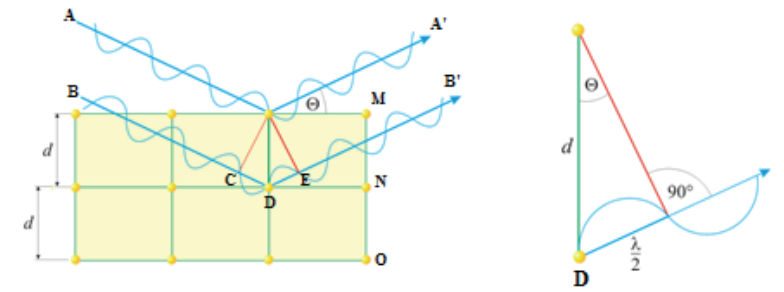

Slika 6. Bragov zakon difrakcije [15]

Ukoliko je zadovoljena Bragova jednačina javlja se konstruktivna interferencija, odnosno reflektovani snopovi su u fazi. Refleksije su difrakcioni maksimumi nastali pozitivnom interferencijom.

Do destruktivne interferencije, odnosno do opadanja intenziteta dolazi ako upadni snop zraka pada na kristal pod uglom različitim od Bragovog ugla $\theta$ [4]. Usled destruktivne interferencije dolazi do međusobnog poništavanja zraka, jer reflektovani zraci nisu u fazi. Zraci reflektovani sa jedne ravni uvek su u fazi s obzirom da prelaze iste puteve $[16,17,18]$.

\section{Difraktogram praha}

Difraktogram praha predstavlja rezultat snimanja nekog polikristalnog materijala na difraktomertu za prah, odnosno može se reći da difraktogram praha predstavlja rezultat dejstva rendgenskih zraka na polikristalnom materijalu. Svaki difraktogram praha sastoji se od pikova. Ono što odlikuje svaki pik je intenzitet i širina na poluvisini. Na apscisi se nalazi položaj pika koji je određen uglom $2 \theta\left(^{\circ}\right)$, dok se na ordinati difraktograma nalazi intenzitet koji je predstavljen brojnim vrednostima. Na slici 7 prikazani su difraktogrami različitih agregatnih stanja materije.
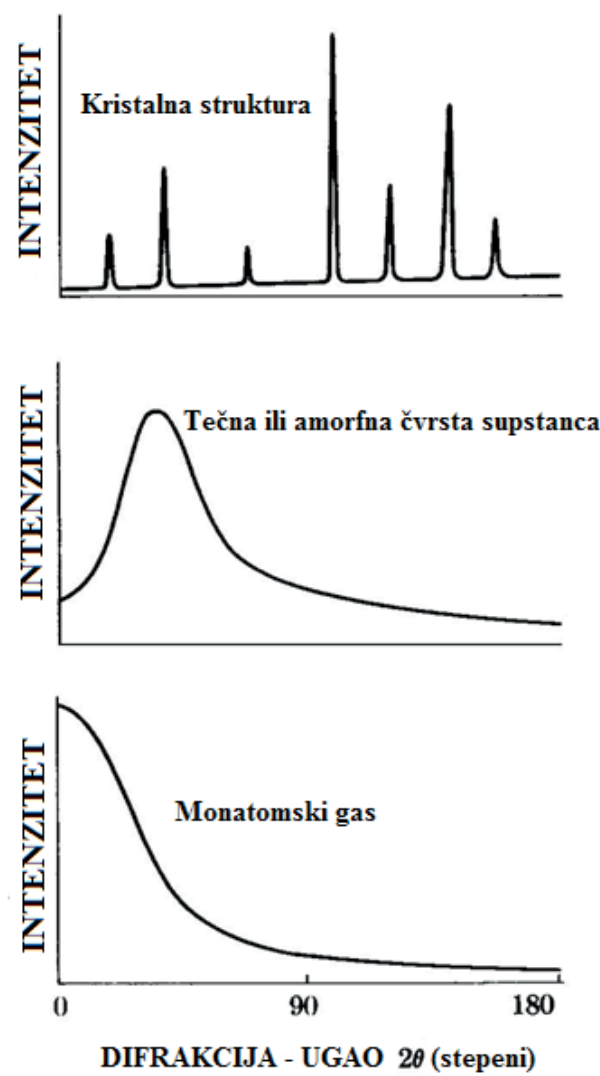

Slika 7. Difraktogrami različitih agregatnih stanja materije [19]

Širina na poluvisini predstavlja širinu difrakcione linije koja se meri na polovini visine pika. Difrakcione linije koje imaju širinu na poluvisini oko $0,1^{\circ} 2 \theta$ definisane su kao oštre [2]. Iz položaja i intenziteta pikova, ako su faze kristalne i ako njihova trodimenzionalna periodičnost nije narušena, može se izvršiti identifikacija određene faze ili faza, njihova zastupljenost kao i struktura.

Kod amorfnih materijala javljaju se široki pikovi [20, 21]. U slučaju da je periodičnost narušena i da čvrsta faza ima nizak stepen kristaliniteta, onda se za takvu fazu kaže da je amorfna, odnosno staklasta. Pikovi na 
difraktogramu praha će biti širi što je stepen kristaliniteta niži, odnosno širina pika je u funkciji stepena kristaliniteta.

Kako realni kristali nemaju savršenu strukturu, tako je svako kristalno zrno sačinjeno od više kristalita između kojih se nalaze granice podzrna. Može se reći da su najčešći uzrok širenja refleksija mali kristaliti dimenzije ispod $0,2 \mu \mathrm{m}$ koji sačinjavaju kristalno zrno. Nezavisnu refleksiju će dati svaki kristalit, ali kao posledica malih razlika u položajima refleksija na difraktogramu praha doći će do formiranja jedne široke refleksije [2].

$\mathrm{Na}$ širenje difrakcionih linija pored veličine kristalita utiču i mikronaprezanja kao posledica mlevenja materijala ili ograničenog rasta kristalnog nukleusa. Ukoliko su kristaliti mali, ispod $50 \AA$, a pri tom postoje mikronaprezanja, neke slabe refleksije mogu nestati, tj. postaju toliko široke da se ne vide na difraktogramu [2].

Dve glavne karakteristike koje određuju izgled difraktograma praha su položaj difrakcionih maksimuma i njihov intenzitet. Položaj maksimuma je u funkciji uslova datih Bragovim zakonom, dok intenzitet zavisi od različitih faktora. Veličina kristalita ima značajan uticaj na izgled difrakcionih maksimuma, odnosno što su kristaliti sitniji, njihova raspodela u prahu je homogenija, ali je širina difrakcionih maksimuma veća [14].

$\mathrm{Na}$ osnovu dobijenih eksperimentalnih vrednosti koji se nalaze na difraktogramu praha, vrši se upoređivanje sa podacima iz literature koji se mogu naći u JCPDS (eng. Joint Committee on Powder Diffraction Standards) datoteci, pri čemu se određuje prisustvo kristalnih faza. Za identifikaciju neke kristalne faze, neophodno je da se svi pikovi na difraktogramu praha poklapaju sa pikovima na JCPDS kartici.

\section{IDENTIFIKACIJA STRUKTURE BAZALTA PRE I POSLE TERMIČKOG TRETMANA UZ PRIMENU XRPD METODE}

Difrakcioni podaci, za ispitivane uzorke, prikupljani su na sobnoj temperaturi na difraktometru za prah proizvođača Rigaku, model Ultima IV. Tokom ispitivanja, korišćeno je $\mathrm{CuKa}_{1,2}$ zračenje $(\lambda=1,54178 \AA$ ) nastalo u rendgenskoj cevi pri jačini struje od $40 \mathrm{~mA}$ i naponu od $40 \mathrm{kV}$. Zračenje je monohromatizovano Ni filterom, pri čemu je filter postavljen ispred detektora. Digitalnim brojačem $\mathrm{D} /$ teX se beleži difraktovano zračenje. $\mathrm{Za}$ dobijanje grafičkog prikaza difraktograma kao i analize korišćen je softver PDXL.
Kao uzorak za ispitivanje, metodom rendgenske difraktometrije praha, korišćen je bazalt sa lokaliteta "Vrelo" Kopaonik, R. Srbija, slika 8. Bazalt je magmatska stena. Pripada grupi tvrdih stena homogene građe. Dugo vreme hlađenja lave na površini zemlje dovodi do stvaranja sitnozrnastog bazalta. Bazalt, zbog svojih svojstava, nalazi široku primenu u mnogim granama privrede, a proizvodi od bazalta mogu biti adekvatna zamena metalnim materijalima.

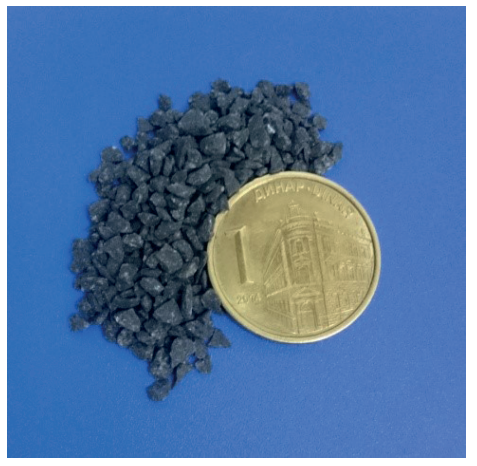

Slika 8. Bazalt sa lokaliteta "Vrelo"

Bazalt, dimenzije od 1 do $3 \mathrm{~mm}$, je usitnjen drobljenjem u merzeru. Usitnjeni bazalt je nakon toga prosejan na veličinu čestica praha ispod $45 \mu \mathrm{m}$, a potom mleven $\mathrm{u}$ ahatnom avanu u cilju dobijanja finog homogenog praha. Materijali visoke tvrdoće, kao što je bazalt, teže se sprašuju, pa je potrebno duže vreme mlevenja. Da bi se dobio verodostojan difraktogram praha, neophodno je dobro sprašiti uzorak, jer što je veći broj čestica praha podvrgnut difrakciji, veća je verovatnoća da se na difraktogramu pojave jasno definisane refleksije kao posledica difrakcije X-zraka.

Kada je prah sprašen, vrši se njegova priprema za ispitivanje. Naime, silicijumski monokristalni nosač uzor$\mathrm{ka}$, površine $1 \mathrm{~cm}^{2}$, se popunjava sprašenim bazaltom, potom se prah pritiska staklenom pločicom, a zatim se uklanja višak praha sa nosača nakon čega je uzorak spreman za snimanje. Veoma je važno napraviti glatku i ravnu površinu na nosaču koja neće narušiti fokusnu geometriju difraktometra.

Intenziteti difrakcionih maksimuma prikupljani su u intervalu od 3 do $65^{\circ} 2 \theta$, sa korakom od $0,02^{\circ}$ i brzinom $2 \%$ min. Dobijeni difraktogram praha bazalta prikazan je na slici 9. 


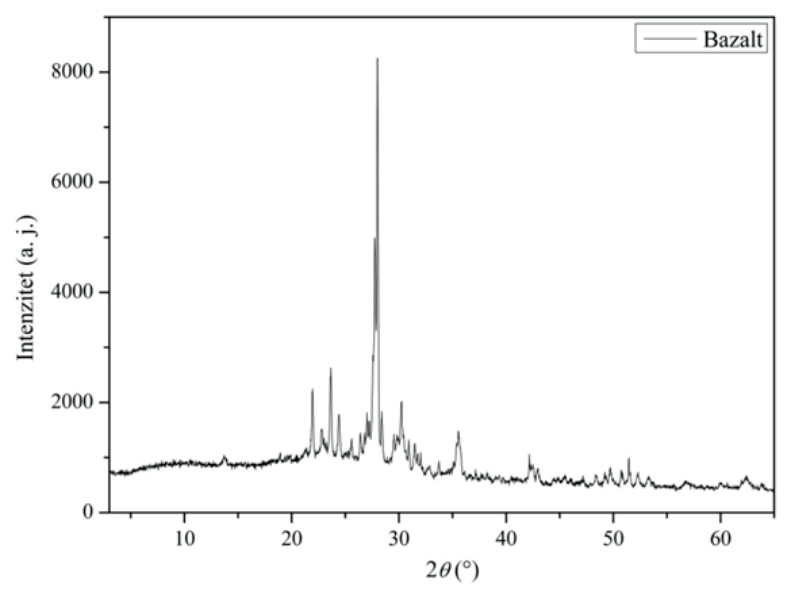

Slika 9. Difraktogram praha bazalta

$\mathrm{Na}$ difraktogramu praha bazalta, slika 9, mogu se uočiti jasno definisani oštri pikovi jakih intenziteta. $\mathrm{Na}$ osnovu difraktograma može se reći da je bazaltni agregat sačinjen od minerala dobre strukturne uređenosti. Nešto malo viši fon ukazuje na prisustvo amorfne faze u bazaltu.

U cilju ispitivanja strukture bazalta usled izlaganja visokoj temperaturi, iznad tačke topljenja, a potom naglom hlađenju, usledio je naredni eksperiment. Naime, prah bazalta je stavljen u korundni tigl zapremine $25 \mathrm{ml}$. Tigl sa uzorkom je zatim postavljen u visokotemperaturnu vakuumsku peć. Temperatura zagrevanja je bila 10 ${ }^{\circ} \mathrm{C} / \mathrm{min}$ sve do temperature od $1400^{\circ} \mathrm{C}$. Uzorak je bio podvrgnut temperaturi od $1400{ }^{\circ} \mathrm{C}$ u periodu od $1 \mathrm{~h}$, a potom hlađen brzinom od $25^{\circ} \mathrm{C} / \mathrm{min}$, s obzirom da peć ima sistem vodenog hlađenja.

Zbog zagrevanja bazalta iznad tačke topljenja, a potom naglim hlađenjem, bazalt se transformiše u bazaltno staklo, odnosno iz kristalne strukture prelazi u amorfnu. Na slici 10 je prikazan poprečni presek tigla sa bazaltnim staklom nakon termičkog tretmana.

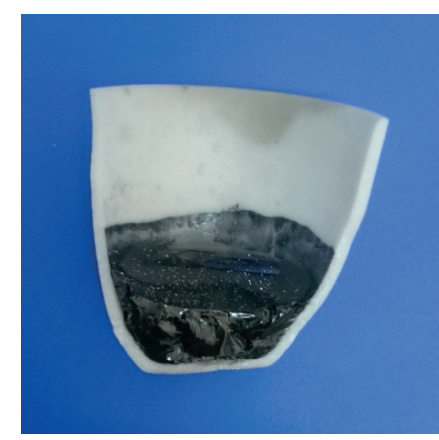

Slika 10. Poprečni presek tigla sa bazaltnim staklom
U cilju identifikacije strukture bazaltnog stakla, tigl je razbijen kako bi se izvadio uzorak. Uzorak je potom izdrobljen i samleven. Usitnjeni prah bazaltnog stakla je zatim snimljen na difraktometru, a kao rezultat je dobijen difraktogram bazaltnog stakla, slika 11. Intenziteti difrakcionih maksimuma prikupljani su u intervalu od 3 do $65^{\circ} 2 \theta$, sa korakom od $0,02^{\circ}$ i brzinom $2 \%$ min.

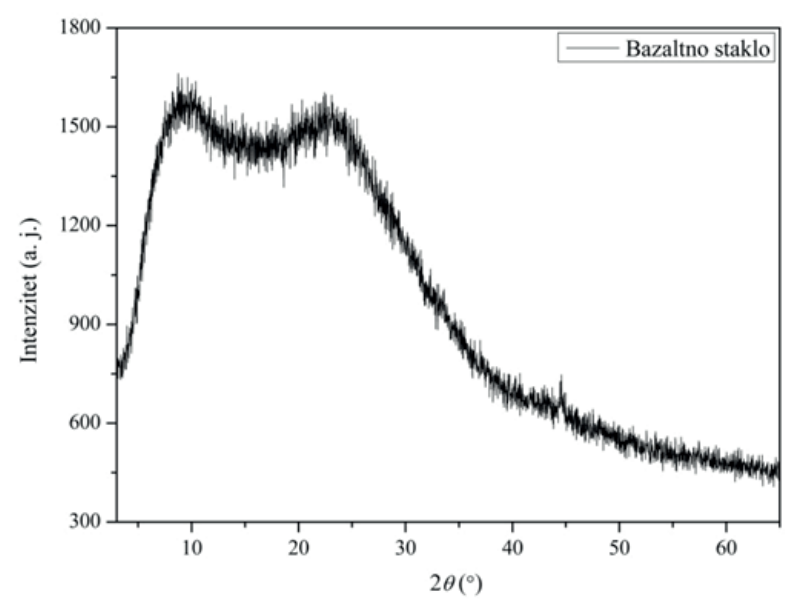

Slika 11. Difraktogram bazaltnog stakla

Na difraktogramu praha bazaltnog stakla, slika 11, može se uočiti široki pik, visokog fona, što ukazuje da je ova faza amorfna. Ukoliko je periodičnost u kristalu narušena i ako čvrsta faza poseduje nizak stepen sređenosti onda se ona naziva staklastom, odnosno amorfnom. Faze niskog stepena sređenosti se lako prepoznaju na difraktogramu po karakterističnim širokim difrakcionim maksimumima pri malim uglovima $2 q$, što se jasno vidi na difraktogramu bazaltnog stakla. Do transformacije kristalne strukture u amorfnu došlo je iz razloga što rastopljeni bazalt zbog naglog pada temperature ne kristališe, već trenutno očvrščava i zadržava amofrnu formu kao staklo.

\section{ZAKLJUČAK}

Za dobijanje faznih kao i strukturnih podataka, na osnovu koji se može izabrati optimalan put od sirovine do finalnog proizvoda željenog sastava i karakteristika, važnu ulogu ima metoda rengdenske difraktometrije praha. Pri ispitivanju faznih transformacija materijala, nastalih tokom različitih tehnoloških procesa, ova metoda je od neprocenjivog značaja.

Za ispitivanje različitih materijala najčešće se koristi metoda praha, a od instrumenata difraktometar za prah 
zbog svojih prednosti, kao što su: jednostavna priprema uzorka, kratko vreme eksperimenta kao i tačnost dobijenih rezultata.

Ovom metodom moguće je izvršiti sledeće analize: utvrđivanje strukture materijala, posredna identifikacija hemijskih elemenata i jedinjenja, kvalitativna fazna analiza, kvantitativna fazna analiza, razmak između susednih atoma, greške u kristalnoj strukturi, veličina, oblik i orijentacija kristalita u uzorku.

$\mathrm{Na}$ osnovu svega nevedenog, XRPD metoda nalazi primenu u mnogim oblastima pri čemu treba posebno izdvojiti: nauku o materijalima, geologiju i farmaciju.

\section{ZAHVALNOST}

Ovaj rad proistekao je iz rezultata istraživanja na projektu Ministarstva prosvete, nauke i tehnološkog razvoja Republike Srbije TR 35024.

\section{LITERATURA}

[1] Lj. Karanović and D. Poleti, Rendgenska strukturna analiza. Zavod za udžbenike i nastavna sredstva, Beograd, 2003.

[2] Lj. Karanović, Primenjena kristalografija. Univerzitet u Beogradu, Beograd, 1996.

[3] N. Kato, "The flow of X-rays and materials waves in ideally perfect single crystals," Acta Crystallographica, vol. 11, pp. 885-887, 1958.

[4] J. Rodrigez-Carvajal, "FULLPROF: A Program for Rietveld Refinement and Pattern Matching Analysis," Abstracts of the Satellite Meeting on Powder Diffraction of the XV Congress of the IUCr, Toulouse, France, p. 127, 1990.

[5] T. Roisnel and J. Rodríquez-Carvajal, "WinPLOTR: A Windows Tool for Powder Diffraction Pattern Analysis," Materials Science Forum, vol. 378-381, pp. 118-123, 2001.

[6] P.J. Potts, A Handbook of Silicate Rock Analysis. Blackie, Glasgow, 1987.

[7] U. S. Geological Survey Open-File Report 01-041 [homepage on the Internet]. X-Ray Diffraction Primer [cited 2019 March 12]. Available from: https:/pubs.usgs.gov/of/2001/of01-041/htmldocs/ images/xrdtube.jpg.
[8] Pawel Szroeder - homepage - Fizyka UMK [homepage on the Internet]. Teaching [cited 2019 March 12]. Available from: http://fizyka.umk.pl/ psz/w09. pdf.

[9] M. Prekajski, Sinteza i karakterizacija nanoprahova u CeO2-Bi2O3 sistemu, doktorska disertacija, Beograd, 2013.

[10] R. Prokić-Cvetković and O. Popović, Mašinski materijali 1. Univerzitet u Beogradu Mašinski fakultet, Beograd, 2012.

[11] C. Hammond, The Basics of Crystallography and Diffraction. IUCr, Oxford University Press Inc., New York, 2000.

[12] G.H. Stout and L.H. Jensen, X-Ray Structure Determination. Wiley, New York, 1989.

[13] H.P. Klug and L.E. Alexander, X-Ray Diffraction Procedures for Polycrystalline and Amorphous Materials, 2nd edition. John Wiley \& Sons, New York, 1974.

[14] R.S. Drago, Physical Methods for Chemists. Surfside Scientific Publishers, Gainesville, 1992.

[15] Croatian-English Chemistry Dictionary \& Glossary [homepage on the Internet]. Chemistry images gallery [cited 2019 March 12]. Available from: https:// glossary.periodni.com/glosar.php?hr=Braggov+kut.

[16] G. Gopalakrishna and R.B. Ramchander, "A study of the relation between the grain size and the dimensions of spots on $\mathrm{x}$-ray diffraction photographs of polycrystalline materials," International Journal of Rock Mechanics and Mining Sciences \& Geomechanics Abstracts, vol. 9, pp. 635-642, 1972.

[17] A.A. Tabikh and R.J. Weht, "An X-ray diffraction analysis of portland cement," Cement and Concrete Research, vol. 2, pp. 156-159, 1972.

[18] V. Jokanović, Instrumentalne metode ključ za razumevanje nanotehnologija i nanomedicine. Inženjerska Akademija Srbije i INN "Vinča”, Beograd, 2014.

[19] B.D. Cullity, Elements of X-Ray Diffraction. Addison-Wesley, 1978.

[20] B.W. James, The optical principles of the diffraction of X-rays. Cornell Univ., 1965.

[21] B.E. Warren, X-ray diffraction. Addison-Wesley, 1969. 